\title{
Clinical findings and risk factors to oral squamous cell carcinoma in young patients: A 12-year retrospective analysis
}

\author{
Hellen-Bandeira-de-Pontes Santos ${ }^{1}$, Thayana-Karla-Guerra dos Santos ${ }^{2}$, Alexandre-Rolim Paz ${ }^{3}$, Yuri-Wan- \\ derley Cavalcanti ${ }^{4}$, Cassiano-Francisco-Weege Nonaka ${ }^{5}$, Gustavo-Pina Godoy ${ }^{5}$, Pollianna-Muniz Alves ${ }^{5}$
}

\footnotetext{
${ }^{1} \mathrm{MsC}$ in Dentistry, Post-graduate Program of Dentistry, State University of Paraíba, Campina Grande, Paraíba, Brazil

${ }^{2} \mathrm{MsC}$ in Dentistry, Post-graduate Program of Dentistry, Federal University of Paraíba, João Pessoa, Paraíba, Brazil

${ }^{3}$ Professor, Department of Pathology, Federal University of Paraíba, João Pessoa, Paraíba, Brazil

${ }^{4}$ Post-Doctoral Fellow at School of Dentistry, State University of Paraíba, Campina Grande, Paraíba, Brazil

${ }^{5}$ Professor, Post-graduate Program of Dentistry, State University of Paraíba, Campina Grande, Paraíba, Brazil
}

Correspondence:

State University of Paraiba

Dentistry Department

Rua das Baraúnas, 351

Bairro Universitário

Campina Grande, Paraiba

Brazil. CEP: 58429-500

pmunizalves@gmail.com

\begin{abstract}
Santos HBP, dos Santos TKG, Paz AR, Cavalcanti YW, Nonaka CFW, Godoy GP, Alves PM. Clinical findings and risk factors to oral squamous cell carcinoma in young patients: A 12-year retrospective analysis. Med Oral Patol Oral Cir Bucal. 2016 Mar 1;21 (2):e151-6.
\end{abstract}

http://www.medicinaoral.com/medoralfree $01 / \mathrm{v} 21 \mathrm{i} 2 /$ medoralv21i2p151.pdf

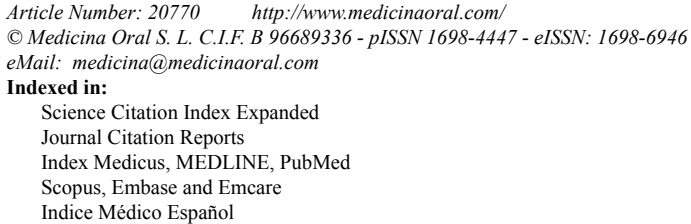

\begin{abstract}
Background: In recent years have been observed an increased incidence of OSCC in young individuals. Based on this, the aim this study was to describe the clinical characteristics of all cases of OSCC in younger patients, diagnosed in two oncology referral hospitals, at the northeast region of Brazil within a 12-year period.

Material and Methods: Data regarding general characteristics of patients (age, gender and tobacco and/or alcohol habits) and information about the lesions (tumor location, size, regional lymph node metastasis, distant metastasis and clinical stage) were submitted to descriptive and inferential analysis. Statistical analysis included Chi-square and Fisher's exact tests $(P<0.05)$.

Results: Out of 2311 registered cases of OSCC, 76 (3.3\%) corresponded to OSCC in patients under 45 years old. Most of them were male $(n=62,81.6 \%)$ and tobacco and/or alcohol users $(n=40,52.8 \%)$. The most frequent site was the tongue ( $\mathrm{n}=31,40.8 \%$ ), with predominance of cases classified at advanced clinical stage (III and IV, $\mathrm{n}=46$, $60.5 \%)$. The advanced stage of OSCC (III and IV) was statistically associated with male gender $(P=0.035)$, lower education level $(P=0.007)$, intraoral sites $(P<0.001)$, presence of pain symptomatology $(P=0.006)$, and consumption of tobacco and/or alcohol $(P=0.001)$.

Conclusions: The profile of OSCC in young patients resembles to the commonly characteristics reported for overall population. The late diagnosis in young patients usually results in poor prognosis, associated with gender, harmful habits and tumor location. Although prevalence is low, stimulus to prevention and to early diagnosis should be addressed to young individuals exposed to risk factors.
\end{abstract}

Key words: Squamous cell carcinoma, head and neck neoplasms, risk factors, young patients, prognosis. 


\section{Introduction}

Oral Squamous Cell Carcinoma (OSCC) is the most frequent malignant neoplasm of oral cavity corresponding to 80 to $90 \%$ of all malignancies (1). OSCC mainly affects men within their sixth and seventh decades of life. An increasing incidence of OSCC among individuals younger than 45 years old has been observed in recent decades, representing approximately $4 \%$ to $13 \%$ of all cases of OSCC (2-8). The tongue is the anatomical site more frequently affected and it is usually associated with alcohol and tobacco use (2,3). Additionally, intensive exposure to sunlight is the main etiological factor for the squamous cell carcinoma at the lower lip (4).

Since young individuals are exposed for a short period of time to significant risk factors (i.e.: extended exposition to sunlight and consumption of tobacco and/or alcohol); studies have suggested that the etiology of OSCC differs between younger and elderly patients (7,9-12). In addition, some studies have suggested that younger patients with OSCC are likely nonsmokers and nondrinkers $(10,11,13)$. Therefore, the literature has pointed out that other factors might be associated with OSCC in young population, such as genetic predisposition, immunological and nutritional alterations and infection by HPV $(7,13,14)$. However, this relationship is still not well established.

In terms of biological behavior and clinical prognosis, evidences suggest that OSCC in younger patients have increased aggressiveness compared to those affecting elderly patients $(4,5,10,15,16)$. However, the definition of prognosis is still hard to determine and improved prognostic characteristics would be clinically useful to determine the biological aggressiveness of OSCC, for both younger and elder patients.

Regional lymph node metastasis, tumor location and TNM classification of malignant tumors (TNM) has been cited as prognostic indicators (17). However, there are scarce studies in the literature regarding the clinical prognostic factors of OSCC in young patients worldwide. Based on that, our study aimed to examine all cases of OSCC in young patients, diagnosed in two oncology hospitals within a 12-year period.

\section{Material and Methods}

\section{- Study design}

A 12-year retrospective and retrolective analysis was conducted with the clinical records of all individuals diagnosed with OSCC, within two oncology referral hospitals, at the northeast region of Brazil. The ethical committee in research of the State University of Paraiba has approved the present investigation under protocol number 163.442. To access the records of all OSCC patients, the principals of the hospitals provided an informed consent form authorizing the use of data for research purposes.
The study population consisted of all cases of OSCC diagnosed in patients under 45 years old, at the oncology referral hospitals. The patients' age at the first OSCC diagnostic determined their allocation within the study population. Recurrent OSCC cases under management and those undergoing radiotherapy or chemotherapy were excluded from the study.

- Variables and data collection methods

General and medical records of individuals included gender, age, race, level of education and tobacco and/ or alcohol habits. Additional information regarding the characteristics of the lesion was also considered, including: tumor location, pain symptomatology, treatment, size of the tumor, presence of regional lymph node metastasis, distant metastasis and clinical stage. The evaluation regarding the clinical stage of lesions was in accordance with the Union for International Cancer Control (UICC) classification of malignant tumors described in 2002. This classification can be used in a way to determine the prognostic of lesions and survival rate of patients $(7,18)$.

- Statistical analysis

Data was analyzed descriptively by the calculation of proportions. Statistical analysis included associations between the characteristics of individuals (gender, education level, pain symptomatology and tobacco and/or alcohol habits) and lesions (size, tumor location, regional lymph node metastasis, distant metastasis and clinical stage). Statistical associations were performed using Chi-square and Fisher's exact tests, at $5 \%$ significance level $(P<0.05)$.

\section{Results}

Out of 2311 registered cases of OSCC, 76 (3.3\%) corresponded to patients under 45 years old. The proportion of OSCC in younger patients, per year, was also determined using the total number of cases within 12 years, as shown in table 1 . Prevalence varied between $2.63 \%$ and $17.11 \%$ and bigger proportion was found in 2010 , showing that prevalence was not regular along the years.

Within the young population studied, age varied between 22 and 45 years with median of $38.38 \pm 6.47$ years old. OSCC affected predominantly male $(\mathrm{n}=62$, $81.6 \%$ ), in a ratio of $4.42: 1$ between men and women. Most of patients declared themselves as "non-white" (n $=40,52.7 \%)$. The level of education among the studied individuals was considered low $(n=43,56.6 \%)$.

Simultaneous use of alcohol and tobacco was the most frequent habit reported $(n=28,36.8 \%)$. With regards to primary tumor location, OSCC affected predominantly tongue $(\mathrm{n}=31,40.8 \%)$ and lower lip $(\mathrm{n}=24,31.6 \%)$ (Table 2). The later corresponded to the only group of tumors located extra-orally. The pain symptomatology was present in $69.7 \%(n=53)$ of patients. With regards 
Table 1. Prevalence of OSCC cases in young patients per year and proportion relative to the total number of cases within 12 years.

\begin{tabular}{|c|c|c|}
\hline Year & $\begin{array}{c}\text { Number (n) } \\
\text { of cases } \\
\text { per year }\end{array}$ & $\begin{array}{c}\text { Proportion (\%) of } \\
\text { cases per } \\
\text { year, relative to total }\end{array}$ \\
\hline 2000 & 7 & 9.21 \\
\hline 2001 & 6 & 7.89 \\
\hline 2002 & 4 & 5.26 \\
\hline 2003 & 4 & 5.26 \\
\hline 2004 & 2 & 2.63 \\
\hline 2005 & 9 & 11.84 \\
\hline 2006 & 6 & 7.89 \\
\hline 2007 & 4 & 5.26 \\
\hline 2008 & 4 & 5.26 \\
\hline 2009 & 5 & 6.58 \\
\hline 2010 & 13 & 17.11 \\
\hline 2011 & 7 & 9.21 \\
\hline 2012 & 5 & 6.58 \\
\hline Total & $\mathbf{7 6}$ & $\mathbf{1 0 0}$ \\
\hline
\end{tabular}

To the total number of cases within 12 years.

to the treatment performed, surgery was frequently associated with radiotherapy and chemotherapy $(\mathrm{n}=36$, 47.4\%) (Table 2).

Based on TNM classification, tumor size "T1" $(\mathrm{n}=27$, $35.5 \%)$ and absence of regional lymph node metastasis "N0" ( $=40,52.6 \%)$ were more frequently reported. Distant metastasis was absent within the population studied $(\mathrm{n}=76,100 \%)$ (Table 3$)$.

Lesions at advanced clinical stage (III and IV, $\mathrm{n}=46$, $60.5 \%)$ were recurrently found at intraoral sites $(\mathrm{n}=38$, $82.6 \%)$, frequently affecting male individuals $(\mathrm{n}=41$, $89.1 \%)$, smokers and drinkers $(\mathrm{n}=31,77.5 \%)$, illiterate $(\mathrm{n}=11,78.6 \%)$ and patients reporting pain symptomatology $(\mathrm{n}=35,66.0 \%)$. Therefore, clinical stage was statistically associated with gender $(P=0.035)$, education level $(P=0.007)$ and tumor location $(P<0.001)$. Similarly, advanced clinical stages were associated with the presence of tobacco and alcohol habits $(P=0.001)$ and pain symptomatology $(P=0.006)$ (Table 4$)$.

\section{Discussion}

Although OSCC is recognized as malignant neoplasm affecting mainly elderly patients, the incidence of OSCC in individuals under 45 years old has increased substantially within the past few years $(4-7,10,12,16)$. Studies have suggested that OSCC develops a more aggressive behavior, with poor prognosis, among young patients $(5,19,20)$. In this census study, the analysis of clinical records from two oncology referral hospitals in the northeast region Brazil has pointed out important risk factors implicated with the etiology and pathogenicity
Table 2. Absolute and relative distributions of OSCC cases in young patients, according to clinical parameters.

\begin{tabular}{|l|c|}
\hline \multicolumn{1}{|c|}{ Clinical parameters } & n (\%) \\
\hline Gender & \\
\hline Male & $62(81.6 \%)$ \\
\hline Female & $14(18.4 \%)$ \\
\hline Race & \\
\hline White & $36(47.3 \%)$ \\
\hline No white & $40(52.7 \%)$ \\
\hline Education level & \\
\hline Illiterate & $14(18.4 \%)$ \\
\hline Low & $43(56.6 \%)$ \\
\hline Medium to high & $19(25.0 \%)$ \\
\hline Primary tumor location & \\
\hline Tongue & $31(40.8 \%)$ \\
\hline Lower lip & $24(31.6 \%)$ \\
\hline Floor of the mouth & $7(9.2 \%)$ \\
\hline Retromolar region & $4(5.3 \%)$ \\
\hline Gingiva & $3(3.9 \%)$ \\
\hline Alveolar ridge & $3(3.9 \%)$ \\
\hline Palate & $3(3.9 \%)$ \\
\hline Upper lip & $1(1.4 \%)$ \\
\hline Symptomatology & \\
\hline Present & $53(69.7 \%)$ \\
\hline Absent & $23(30.3 \%)$ \\
\hline Harmful Habits & $28(36.8 \%)$ \\
\hline Smoking + Alcohol consumption & $10(13.2 \%)$ \\
\hline Smoking & $2(2.6 \%)$ \\
\hline Alcohol consumption & $23(30.3 \%)$ \\
\hline No habits & $19(25.0 \%)$ \\
\hline Unreported & $21(27.6 \%)$ \\
\hline Treatment & $36(47.4 \%)$ \\
\hline Surgery & \\
\hline Radiotherapy and/or Chemotherapy & \\
\hline Surgery + Radiotherapy and/or Chemotherapy & \\
\hline & \\
\hline
\end{tabular}

of OSCC among young individuals, resulting in a consistent epidemiological profile for this age group.

Out of the 2311 cases of OSCC, $3.3 \%$ were diagnosed in young patients, as similarly shown by the literature $(6,12)$. However, greater prevalence of OSCC among young individuals was informed by other studies, with prevalence ranging from $12 \%$ to $14 \%(4,8,10)$. In the present study, the prevalence of OSCC varied between $2.63 \%$ and $17.11 \%$, not showing any pattern of manifestation along the years. Regional, socioeconomic and cultural characteristics of different populations may explain the discrepancy found in the reported prevalence of OSCC by various studies with diverse methodological design.

The population included in the present study has cultural habit to consume alcohol and tobacco since first years of adulthood. This aspect might be associated with increased prevalence of OSCC in tongue (40.8\%). Additionally, the population of present study is exposed to high incidence of sunlight radiation, due to the proxi- 
Table 3. Absolute and relative distributions of OSCC cases in young patients, according to tumor size, nodal metastasis, distant metastasis and clinical stage.

\begin{tabular}{|l|c|}
\hline \multicolumn{1}{|c|}{$\begin{array}{c}\text { Clinical } \\
\text { parameters }\end{array}$} & n (\%) \\
\hline T & $27(35.5 \%)$ \\
\hline T1 & $19(25.0 \%)$ \\
\hline T2 & $12(15.8 \%)$ \\
\hline T3 & $18(23.7 \%)$ \\
\hline T4 & \\
\hline N & $40(52.6 \%)$ \\
\hline N0 & $17(22.4 \%)$ \\
\hline N1 & $11(14.5 \%)$ \\
\hline N2 & $8(10.5 \%)$ \\
\hline N3 & \\
\hline M & $76(100 \%)$ \\
\hline M0 & $0(0 \%)$ \\
\hline M1 & \\
\hline Clinical stage & $22(28.9 \%)$ \\
\hline I & $8(10.5 \%)$ \\
\hline II & $20(26.3 \%)$ \\
\hline III & $26(34.3 \%)$ \\
\hline IV & \\
\hline & \\
\hline
\end{tabular}

Table 4. Absolute and relative distributions of OSCC cases in young patients, regarding the association between clinical data and clinical stage.

\begin{tabular}{|c|c|c|c|c|}
\hline \multirow[b]{2}{*}{ Clinical data } & \multicolumn{3}{|c|}{ Clinical stage } & \multirow[b]{2}{*}{$p$} \\
\hline & $\begin{array}{l}\text { I - II } \\
\text { n }(\%)\end{array}$ & $\begin{array}{c}\text { III - IV } \\
\text { n (\%) }\end{array}$ & $\begin{array}{l}\text { Total } \\
\text { n }(\%)\end{array}$ & \\
\hline \multicolumn{5}{|l|}{ Gender } \\
\hline Male & $21(33.9)$ & $41(66.1)$ & $62(100.0)$ & \multirow[t]{2}{*}{$0.035 *$} \\
\hline Female & $9(64.3)$ & $5(35.7)$ & $14(100.0)$ & \\
\hline \multicolumn{5}{|l|}{ Education level } \\
\hline Illiterate & $3(21.4)$ & $11(78.6)$ & $14(100.0)$ & \multirow[t]{3}{*}{$0.007 * *$} \\
\hline Low & $17(39.5)$ & $26(60.5)$ & $43(100.0)$ & \\
\hline Medium to High & $14(73.7)$ & $5(26.3)$ & $19(100.0)$ & \\
\hline \multicolumn{5}{|l|}{$\begin{array}{l}\text { Primary tumor } \\
\text { location }\end{array}$} \\
\hline Intraoral sites & $13(25.5)$ & $38(74.5)$ & $51(100.0)$ & \multirow[t]{2}{*}{$<0.001 *$} \\
\hline Extraoral sites & $17(68.0)$ & $8(32.0)$ & $25(100.0)$ & \\
\hline \multicolumn{4}{|l|}{ Symptomatology } & \multirow{3}{*}{$0.006 *$} \\
\hline Present & $18(34.0)$ & $35(66.0)$ & $53(100.0)$ & \\
\hline Absent & $16(69.5)$ & $7(30.4)$ & $23(100.0)$ & \\
\hline \multicolumn{5}{|l|}{ Harmful habits } \\
\hline Present & $9(22.5)$ & $31(77.5)$ & $38(100.0)$ & \multirow[t]{2}{*}{$0.001 * *$} \\
\hline Absent & $10(76.9)$ & $3(23.1)$ & $13(100.0)$ & \\
\hline
\end{tabular}

*Chi-square test ${ }^{* *}$ Fisher's exact test. mity of the region to the equatorial line. This fact may be associated high prevalence of OSCC at the lower lip (31.6\%). Tumors affecting the tongue, the floor of the mouth and the lower lip have been included as the most frequent location on OSCC independently of age group $(1,4,11,20)$. Furthermore, individuals with diagnostic of OSCC in the present study were predominantly men with low educational level. As demonstrated by the statistical analysis performed, those characteristics were significantly associated with advanced clinical stage of OSCC.

With regards to gender, higher prevalence of OSCC has been frequently reported among male individuals, independently of the age group $(8,10,11,21)$. Our study corroborates the literature, since $81.6 \%(n=62)$ of OSCC occurred in men $(4,6,8,10,11,22,23)$. In contrast, other studies have found higher prevalence of OSCC in young female patients $(12,24)$. Different population characteristics such as genetic predisposition, altered immune and hormonal modulations and infections by HPV may explain the differences within the prevalence between genders $(5,10)$.

The etiology of OSCC is considered complex due to its multifactorial characteristic $(4,8,10,11,15,16,20-27)$. Tobacco and alcohol consumption have been firmly stated as important risk factors for OSCC among elderly people. However, the ability of those habits develop OSCC in youth population is questionable $(4,10,15,28)$.

In the present study, tobacco and/or alcohol consump- tion was frequently presented (75.4\%), which reflects a cultural and social habit frequently present during early adulthood in developing countries such as Brazil (4). The current report confirmed not only the association between OSCC and tobacco and/or alcohol consumption, but also suggested the relation with advanced clinical stage. Additional data relative to tobacco and/or alcohol habits, as age of starting and quantity of consumption per day was not available, therefore we declare the lack of this relevant information as a limitation of our study. Of course, others risk factors might be associated with occurrence of OSCC among young patients (e.g. hereditary predisposition, syndromes, bad nutrition, immunesuppression and HPV infection) (4,9-11,14,20,25-29). However, those aspects were not object of the present investigation.

The prevalence of OSCC at advanced stages (III and IV) was high (60.6\%) and corroborated other investigations $(4,5)$. Besides that, advanced stages (III and IV) of OSCC in young patients were statistically associated with male gender, lower education level, intraoral tumors, pain symptomatology and consumption of tobacco and/or alcohol. Analogous relationship has been reported to OSCC among elderly people $(2,3)$. Therefore, based in our results, we suggested that these conditions must be considered as relevant risk factors to the development of OSCC in young patients. Poor prognosis and lower survival rates are expected among patients under those risk factors. 
In contrast with the worst prognosis of intraoral lesions, extra-oral tumors (detected predominantly at lower lip) were diagnosed at initial stages. Besides the lower aggressiveness (30), those lesions are anatomically located at easily detectable sites, which allows earlier diagnoses. Therefore, due to early diagnostic, a better prognosis and extended survival rate would be expected for those patients. Studies regarding the etiology and pathogenicity of OSCC at lower lip of young patients are scarce within the literature.

Early diagnostic of carcinogenic lesions has been reported among young (27) and female populations (29). Possibly, those individuals have greater ability to detect alterations within their anatomical structures, being also more concerned about their own healthcare. The present investigation has shown that young women had lower prevalence of OSCC and also detected those alterations within early stages of development $(P=0.035)$. In general, the prevalence of OSCC among young patients was low in comparison to literature; however, preventive measures should be implemented and stimulus to early diagnosis must be enforced considering the risk factors pointed out by the present study.

Within the limitations of the present study, the following conclusions can be drawn. The clinical and epidemiological profile of young patients affected by OSCC is similar to that reported to elderly population. Higher prevalence and poor prognosis of OSCC among young patients are associated with male gender, lower educational level, and pain symptomatology. Furthermore, consumption of alcohol and tobacco, as well as tumors located intraorally are significantly associated with high prevalence and poor prognosis of OSCC among young individuals. Further investigations should consider other multi-centric approaches to elucidate the etiology and biological behavior of OSCC in young patients.

\section{References}

1. Johnson NW, Jayasekara P, Amarasinghe AA. Squamous cell carcinoma and precursor lesions of the oral cavity: epidemiology and aetiology. Periodontol 2000. 2011;57:19-37.

2. Albuquerque R, Lopez-Lopez J, Mari-Roig A, Jane-Salas E, Rosello-Llabres X, Santos JR. Oral tongue squamous cell carcinoma (OTSCC): alcohol and tobacco consumption versus non-consumption. A study in a Portuguese population. Braz Dent J. 2011;22:517-21.

3. Moyses RA, López RV, Cury PM, Siqueira SA, Curioni OA, Gois Filho JF, et al. Significant differences in demographic, clinical, and pathological features in relation to smoking and alcohol consumption among 1,633 head and neck cancer patients. Clinics (Sao Paulo). 2013;68:738-44.

4. Ribeiro AC, Silva AR, Simonato LE, Salzedas LM, Sundefeld ML, Soubhia AM. Clinical and histopathological analysis of oral squamous cell carcinoma in young people: a descriptive study in Brazilians. Br J Oral Maxillofac Surg. 2009;47:95-8.

5. Soudry E, Preis M, Hod R, Hamzany Y, Hadar T, Bahar G, et al. Squamous cell carcinoma of the oral tongue in patients younger than 30 years: clinicopathologic features and outcome. Clin Otolaryngol. 2010;35:307-12.
6. Udeabor SE, Rana M, Wegener G, Gellrich NC, Eckardt AM. Squamous cell carcinoma of the oral cavity and the oropharynx in patients less than 40 years of age: a 20 -year analysis. Head Neck Oncol. 2012;4:28

7. Majchrzak E, Szybiak B, Wegner A, Pienkowski P, Pazdrowski J, Luczewski L, et al. Oral cavity and oropharyngeal squamous cell carcinoma in young adults: a review of the literature. Radiol Oncol. 2014;48:1-10.

8. Monteiro LS, Amaral JB, Vizcaíno JR, Lopes CA, Torres FO. A clinical-pathological and survival study of oral squamous cell carcinomas from a population of the North of Portugal. Med Oral Patol Oral Cir Bucal. 2014;19:e120-6.

9. Toner M, O'Regan EM. Head and neck squamous cell carcinoma in the young: a spectrum or a distinct group? Part 1 . Head Neck Pathol. 2009;3:246-8.

10. Falaki F, Dalirsani Z, Pakfetrat A, Falaki A, Saghravanian N, Nosratzehi T, et al. Clinical and histopathological analysis of oral squamous cell carcinoma of young patients in Mashhad, Iran: a retrospective study and review of literature. Med Oral Patol Oral Cir Bucal. 2011;16:e473-7.

11. Troeltzch M, Knösel T, Eichinger C, Probst F, Troeltzsch M, Woodlock T, et al. Clinicopathologic features of oral squamous cell carcinoma: do they vary in different age groups? J Oral Maxillofac Surg. 2014;72:1291-300.

12. Patel SC, Carpenter WR, Tyree S, Couch ME, Weissler M, Hackman $\mathrm{T}$, et al. Increasing incidence of oral tongue squamous cell carcinoma in young white women, age 18 to 44 years. J Clin Oncol. 2011;29:1488-94.

13. Kaminagakura E, Villa LL, Andreoli MA, Sobrinho JS, Vartanian JG, Soares FA, et al. High-risk human papillomavirus in oral squamous cell carcinoma of young patients. Int J Cancer. 2012;130:172632.

14. Nelke KH, Lysenko L, Leszczyszyn J, Gerber H. Human papillomavirus and its influence on head and neck cancer predisposition. Postepy Hig Med Dosw (Online). 2013;67:610-6.

15. Mesquita JA, Queiroz LM, Silveira ÉJ, Gordon-Nunez MA, Godoy GP, Nonaka CF, et al. Association of immunoexpression of the galectins -3 and -7 with histopathological and clinical parameters in oral squamous cell carcinoma in young patients. Eur Arch Otorhinolaryngol. 2016;273:237-43.

16. Fonseca FP, Coletta RD, Azevedo MB, Prado Ribeiro AC, Pires Soubhia AM, Miyahara GI, et al. Stromal myofibroblasts in squamous cell carcinoma of the tongue in young patients - a multicenter collaborative study. Oral Surg Oral Med Oral Pathol Oral Radiol. 2014;118:483-9.

17. Alves PM, Godoy GP, Gomes DQ, Medeiros AM, de Souza LB, da Silveira EJ, et al. Significance of galectins-1, $-3,-4$ and -7 in the progression of squamous cell carcinoma of the tongue. Pathol Res Pract. 2011;207:236-40.

18. Lindenblatt RC, Martinez GL, Silva LE, Faria PS, Camisasca DR, Lourenço SQ. Oral squamous cell carcinoma grading systems--analysis of the best survival predictor. J Oral Pathol Med. 2012;41:34-9.

19. Garavello W, Spreafico R, Gaini RM. Oral tongue cancer in young patients: a matched analysis. Oral Oncol. 2007;43:894-7.

20. Durr ML, van Zante A, Li D, Kezirian EJ, Wang SJ. Oral tongue squamous cell carcinoma in never-smokers: analysis of clinicopathologic characteristics and survival. Otolaryngol Head Neck Surg. 2013;149:89-96.

21. Fronie A, Bunget A, Afrem E, Preoţescu LL, Corlan Puşcu D, Streba L, et al. Squamous cell carcinoma of the oral cavity: clinical and pathological aspects. Rom J Morphol Embryol. 2013;54:343-8. 22. Mallet Y, Avalos N, Le Ridant AM, Gangloff P, Moriniere S, Rame JP, et al. Head and neck cancer in young people: a series of 52 SCCs of the oral tongue in patients aged 35 years or less. Acta Otolaryngol. 2009;129:1503-8.

23. Bodner L, Manor E, Friger MD, van der Waal I. Oral squamous cell carcinoma in patients twenty years of age or younger--review and analysis of 186 reported cases. Oral Oncol. 2014;50:84-9. 
24. Harris SL, Thorne LB, Seaman WT, Hayes DN, Couch ME, Kimple RJ. Association of p16(INK4a) overexpression with improved outcomes in young patients with squamous cell cancers of the oral tongue. Head Neck. 2011;33:1622-7.

25. Koo K, Barrowman R, McCullough M, Iseli T, Wiesenfeld D. Non-smoking non-drinking elderly females: a clinically distinct subgroup of oral squamous cell carcinoma patients. Int J Oral Maxillofac Surg. 2013;42:929-33.

26. Fan Y, Zheng L, Mao MH, Huang MW, Liu SM, Zhang J, et al. Survival analysis of oral squamous cell carcinoma in a subgroup of young patients. Asian Pac J Cancer Prev. 2014;15:8887-91.

27. van Monsjou HS, Wreesmann VB, van den Brekel MW, Balm AJ. Head and neck squamous cell carcinoma in young patients. Oral Oncol. 2013;49:1097-102.

28. Vargas-Ferreira F, Nedel F, Etges A, Gomes AP, Furuse C, Tarquinio SB. Etiologic factors associated with oral squamous cell carcinoma in non-smokers and non-alcoholic drinkers: a brief approach Braz Dent J. 2012;23:586-90.

29. Llewellyn CD, Linklater K, Bell J, Johnson NW, Warnakulasuriya KA. Squamous cell carcinoma of the oral cavity in patients aged 45 years and under: a descriptive analysis of 116 cases diagnosed in the South East of England from 1990 to 1997. Oral Oncol. 2003;39:106-14.

30. da Silveira EJ, Miguel MC, Lima KC, Freitas RA, de Morais ML, Queiroz LM. Analysis of local immunity in squamous cell carcinoma of the tongue and lower lip. Exp Mol Pathol. 2010;88:171-5.

\section{Acknowledgments}

The authors thank the National Council for Scientific and Technological Development-CNPq for financial support (process number: 485788/2013-6).

\section{Conflict of Interest}

Authors also declare no conflicts of interest. 